УДК 615.15:159.9.072.43

DOI: 10.15587/2519-4852.2019.178131

\title{
SOCIOMETRY AS A METHOD FOR ASSESSING THE SOCIO-PSYCHOLOGICAL CLIMATE IN PHARMACIES
}

\author{
N. Andrienko, R. Sahaidak-Nikitiuk, N. Demchenko, N. Alekhina
}

\begin{abstract}
Мета. Метою дослідження є адаптаџія соиіометричного методу оцінювання соиіально-психологічного клімату, щзо склався в аптечному закладі, завдяки розробиі опитувальника, побудові соціоматриці та розробияі соиіограми.

Матеріали та методи. У дослідженні застосовувалися методи узагальнення, аналізу та синтезу, контент-аналізу. Для визначення рівня сочіально-психологічного клімату в аптечному закладі застосовувалися сочіологічне опитування. В опитуванні брали участь всі члени колективу, які працюють в закладі. Дослідження охоплювало всі регіони України. Загальна кількість аптек, які брали участь в соціологічному дослідженні, складає 92 аптеки. Достовірних анкет - 51. Деякі фахівиі фармації обирали недостовірні відповіді - «вибираю всіх» або «з усіма». Такі відповіді пояснюються недефіренційованістю та аморфністю відносин в колективі або наданням свідомо невірних відповідей.
\end{abstract}

Результати. Досліджено теоретичні засади оцінювання соціально-психологічного клімату. Обгрунтовано актуальність вивчення міжособистісних відносин та конфліктних ситуацій, які склалися в колективі, шуо впливає на стан фахівия, його працездатність і якість обслуговування ним відвідувачів аптеки. Доведено дочільність застосування соиіометричного методу для оиінювання соціально-психологічного клімату, який склався в аптечному закладі. Запропоновано алгоритм проведення сочіометричного дослідження в аптечному закладі. Розроблено сочіометричну картку, яку доцільно використовувати для оцінювання соиіально-психологічного клімату аптечного закладу. Наведено форму підсумкової соиіоматрииุi та соиіограми-мішені. Запропоновано визначення величини соціометричного статусу та емоційної експансивності фахівиів фармації аптечного закладу.

Висновки. Проведене дослідження дозволило дійти висновку, щзо для оцінювання СПК, який склався в аптечному заклад $i$, доиільно застосовувати соиіометричний метод, адаптований до умов фармації

Ключові слова: сочіально-психологічний клімат, аптечний заклад, сочіометрія, оцінювання, фахівецьь фармації

Copyright (C) 2019, N. Andrienko, R. Sahaidak-Nikitiuk, N. Demchenko, N. Alekhina. This is an open access article under the CC BY license (http://creativecommons.org/licenses/by/4.0).

\section{Introduction}

In modern conditions of a dynamically developing society, the shift in the pharmacy institution (PHI) of emphasis on the provision of high-quality and timely pharmaceutical assistance to visitors, the profession of "pharmacist" is classified as socially oriented. The social approach in professional activity takes into account not only the characteristics of the specialist, but also the mechanisms of his social behavior, both with visitors and colleagues, management and partners of the PHI, which depends not only on the ability to withstand high emotional load, ability to communicate, but also socio-psychological climate in the collective of the institution [1].

Social competence, and popularity have been investigated in [2]; social psychology [3, 4]; psychological processes in aggression [5]; social analysis [6, 7]; popularity and social acceptance $[8,9]$; sociometry $[10]$.
Though these papers are devoted to the theoretical questions of the social-psychological climate of the team or to the study of the state of the social-psychological climate, which has developed in certain PHI. At the same time, they do not take into account the approaches to the assessment of the socio-psychological climate in the PHI or the specific functioning of the institution, taking into account the requirements of good pharmacy practice.

The purpose of the study is to adapt the sociometric method of assessment of socio-psychological climate in the pharmacy due to questionnaire design, the construction sociometric matrix and development of sociogram.

\section{Planning (methodology) research}

On the basis of the conducted researches it is determined that it is advisable to carry out sociometric research in seven stages (Fig. 1). 


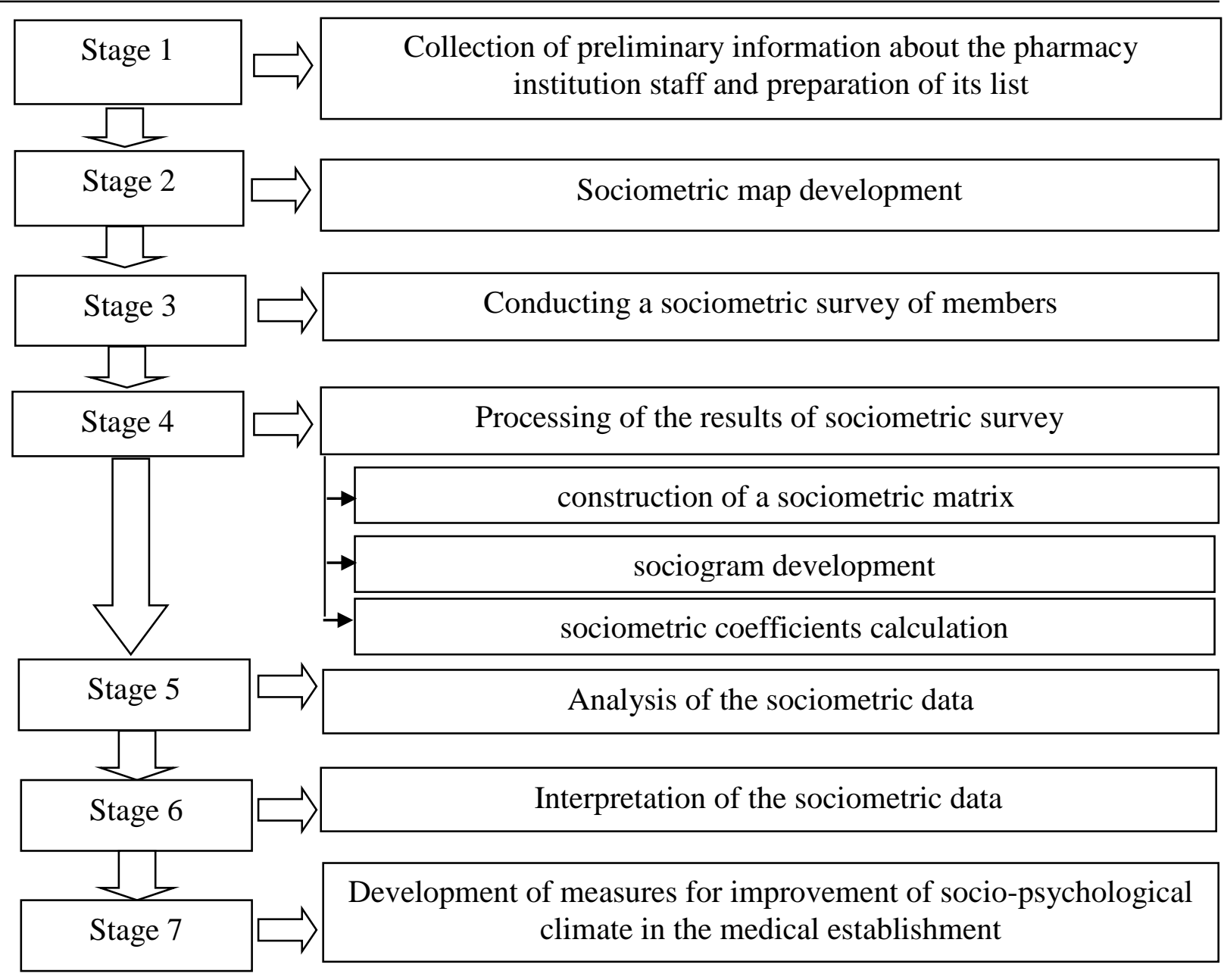

Fig. 1. The algorithm of sociometric research in PHI

At the first stage, information about the pharmacy team is collected and a list of employees is compiled. A questionnaire is then developed for conducting a sociometric study. At the third stage, a sociometric survey of PHI team members takes place directly, followed by processing of the obtained data and their interpretation is carried out. Based on the results obtained, measures are being developed to improve the socio-psychological climate in the team.

\section{Materials and methods}

The study used the methods of generalization, analysis and synthesis, content analysis. A sociological survey was used to determine the level of the sociopsychological climate in PHI. The survey was attended by all members of the staff working in the institution. The study covered all regions of Ukraine. The total number of pharmacies that participated in the sociological survey was 92 pharmacies. There were 51 valid questionnaires. Some pharmacy experts chose incorrect answers - "I choose everyone" or "with everyone". Such answers are explained by the indifference and amorphousness of the relationships within the team or by providing deliberately incorrect answers. Therefore, these questionnaires were not taken into account during processing the data. In the course of sociometric research, it is necessary to measure the sociometric constraint, which takes into account the probability of a random sociometric choice event and the number of team members. Usually, the probability of a random event of a sociometric choice is in the range of $0.20-0.30$.

\section{Results}

The pressing issue of the current PHI is the study of interpersonal relationships and conflict situations that have developed in the team, which affects the state of the specialist, his work capacity, and, accordingly, the quality of service to pharmacy visitors. One of the most popular methods of determining interpersonal relationships in a group is sociometry, which is a field of social psychology that studies the relationships of people in groups, that is, the relation of the pharmacy specialist to the collective and the pharmacy team to the specialist, determined using sociometric criteria. After conducting a sociometric experiment, the pharmacy manager receives information about each specialist's personal position regarding interpersonal relationships and the climate of the staff in PHI [11].

The main purpose of sociometry is to study the sympathy and dislikes that have formed in the team of PHI, and based on the obtained results, the development of appropriate measures that will improve the social and psychological climate in the institution.

A distinctive feature of sociometry is that, unlike questionnaires and interviews, questions relate to the emotional sphere of people's relationships. 
Based on the research, it was determined that 6 questions are appropriate for the number of questions in the social card, and they should be both positive and negative. The optimal duration of the socio- metric survey should not exceed the 5 minutes required to complete the questionnaire after instructing. The form of the card, adapted for the conditions of PHI, is shown in Fig. 2.

\section{SOCIOMETRIC CARD \\ Instruction:}

Your pharmaceutical facility is the one whole organism. You have been working together for some time, so you have studied the character of each other and there are certain business and personal relationships between you.

In order to increase the effectiveness of the team and development of the institution, it is necessary to investigate and take into account all aspects of the relationship between its members. Sociometric research is aimed at examining relationships in your pharmaceutical institution. Please fill in the form.

Full name

\section{Sociometric survey form}

Age _ Total work experience (years) __ Sex F, M

\begin{tabular}{|c|c|c|c|c|}
\hline \multirow[t]{2}{*}{ № } & \multirow[t]{2}{*}{ Criterion } & \multicolumn{3}{|c|}{ Full name of colleague } \\
\hline & & 1 & 2 & 3 \\
\hline 1 & In the event of a reformulation, who would you like to work with? & & & \\
\hline 2 & $\begin{array}{l}\text { In the event of a reformulation, who would you not want to work } \\
\text { with? }\end{array}$ & & & \\
\hline 3 & Which of your colleagues do you have a friendly relationship with? & & & \\
\hline 4 & Which co-worker do you have a friendly relationship with? & & & \\
\hline 5 & Which one of your colleagues you would not like to ask for advice? & & & \\
\hline 6 & $\begin{array}{l}\text { Which of your colleagues you work with you would like to ask for } \\
\text { advice? }\end{array}$ & & & \\
\hline
\end{tabular}

under the number 1 is the name of the team member you would have chosen first, under the number 2 - who would you have chosen if it were not for the first, under the number 3 - who would you have chosen if it had not been for the first and second

Fig. 2. Form of sociometric card adapted to PHI

Interviewed pharmacy experts are invited to include at their discretion three or three colleagues in the group. The wording of "all" and "nobody" is not acceptable. Each answer is assigned a score of $+3,+2,+1$, or $-3,-2,-1$, depending on the rank, which indicates the priority of the choice. Yes, the choice is equal to +3 $(-3)$, in the second $-+2(-2)$, in the third $-+1(-1)$. Then, based on the obtained data, a sociometric matrix is formed, which is a table with the distribution of individual choices that characterize the relationship between a pharmacy specialist and members of the labor collective, consumers, partners or other persons. Due to the fact that the sociometric matrix is built for a specific pharmacy institution, we publish a fragment of research. For example, a pharmacy located in the Kyiv region was selected. An example of a sociometric matrix formed for a pharmacy "A" (for confidentiality) is given in Table 1.

On the basis of the filled proposed by us sociometric matrix a sociogram is constructed, which al- lows to visualize the results, to see clearly the picture of the formed relationships in the team $[12,13]$. Analyse of the sociogram determines professionals who use the authority of colleagues and those with whom colleagues do not communicate ("isolated") or who do not want to work. Sociogram of the investigated PHI is shown in Fig. 3.

The following graphical markings are distinguished in sociograms: gender characteristic of pharmacy specialists:

men - $\square$,women - O;

positive choice: unilateral $\rightarrow$, reciprocal $\leftrightarrow$;

negative choice: unilateral $--\rightarrow$, reciprocal $\leftarrow-\rightarrow$; mutual choice:- double line.

The next step in conducting a sociological survey is to calculate the sociometric indices used to deepen the results of a sociometric survey [14, 15] proposed by us. A summary table of the results of the calculation of sociometric indices of pharmacy " $\mathrm{A}$ " is presented in table 2 . 
Table 1

Total socio-matrix of pharmacy "A"

\begin{tabular}{|c|c|c|c|c|c|c|c|c|c|c|c|c|c|c|c|c|c|c|}
\hline \multirow{2}{*}{\multicolumn{2}{|c|}{$\begin{array}{l}\text { The name of the } \\
\text { specialist you choose }\end{array}$}} & \multicolumn{9}{|c|}{ Name of the specialist who chooses } & \multicolumn{3}{|c|}{$\begin{array}{c}\text { Number of } \\
\text { received } \\
\text { election }\end{array}$} & \multicolumn{3}{|c|}{$\begin{array}{l}\text { Number of } \\
\text { points } \\
\text { obtained }\end{array}$} & \multicolumn{2}{|c|}{$\begin{array}{l}\text { Number of } \\
\text { mutual } \\
\text { points }\end{array}$} \\
\hline & & 1 & 2 & 3 & 4 & 5 & 6 & 7 & 8 & 9 & $\mathrm{~K}^{+}$ & $\mathrm{K}^{\mathrm{o}}$ & $\mathrm{K}^{-}$ & $\mathrm{K}^{+}$ & $\mathrm{K}^{-}$ & $\sum \mathrm{K}$ & $\mathrm{K}^{++}$ & $\mathrm{K}$ \\
\hline $\mathrm{A}$ & 1 & & +2 & +2 & +3 & +2 & 0 & +3 & +4 & +3 & 7 & 1 & 0 & 19 & 0 & 19 & 4 & \\
\hline $\mathrm{B}$ & 2 & +1 & & +3 & +6 & +2 & +6 & +3 & -1 & +5 & 7 & 0 & 1 & 26 & -1 & 25 & 4 & 1 \\
\hline $\mathrm{C}$ & 3 & -2 & +2 & & +5 & +6 & +1 & +6 & 0 & +4 & 6 & 1 & 1 & 24 & -2 & 22 & 3 & \\
\hline $\mathrm{D}$ & 4 & +4 & 0 & 0 & & +3 & +3 & +2 & +1 & 0 & 5 & 3 & 0 & 13 & 0 & 13 & 2 & \\
\hline $\mathrm{E}$ & 5 & +6 & +3 & +3 & +1 & & +9 & -3 & -2 & -2 & 5 & 0 & 3 & 22 & -7 & 15 & 5 & \\
\hline $\mathrm{F}$ & 6 & +5 & -1 & -2 & -1 & +6 & & -1 & 0 & +1 & 3 & 1 & 4 & 12 & -5 & 7 & 1 & \\
\hline $\mathrm{G}$ & 7 & -2 & 0 & -3 & 0 & +4 & 0 & & +2 & +2 & 3 & 3 & 2 & 8 & -5 & 3 & & \\
\hline $\mathrm{H}$ & 8 & 0 & -2 & +1 & 0 & 0 & -1 & 0 & & -3 & 1 & 4 & 3 & 1 & -6 & -5 & & 2 \\
\hline $\mathrm{I}$ & 9 & +1 & +1 & +1 & +2 & +3 & 0 & -1 & +1 & & 6 & 1 & 1 & 9 & -1 & 8 & 3 & \\
\hline \multicolumn{19}{|c|}{$\begin{array}{l}\text { Number of the choice } \\
\text { made: }\end{array}$} \\
\hline \multicolumn{2}{|c|}{ positive $\left(\mathrm{K}^{+}\right)$} & 5 & 4 & 5 & 5 & 7 & 4 & 4 & 4 & 5 & 43 & & & & & & & \\
\hline \multicolumn{2}{|c|}{ neutral $\left(\mathrm{K}^{0}\right)$} & 1 & 2 & 1 & 2 & 1 & 3 & 1 & 2 & 1 & & 14 & & & & & & \\
\hline \multicolumn{2}{|c|}{ negative $\left(\mathrm{K}^{-}\right)$} & 2 & 2 & 2 & 1 & & 1 & 3 & 2 & 2 & & & 15 & & & & & \\
\hline
\end{tabular}

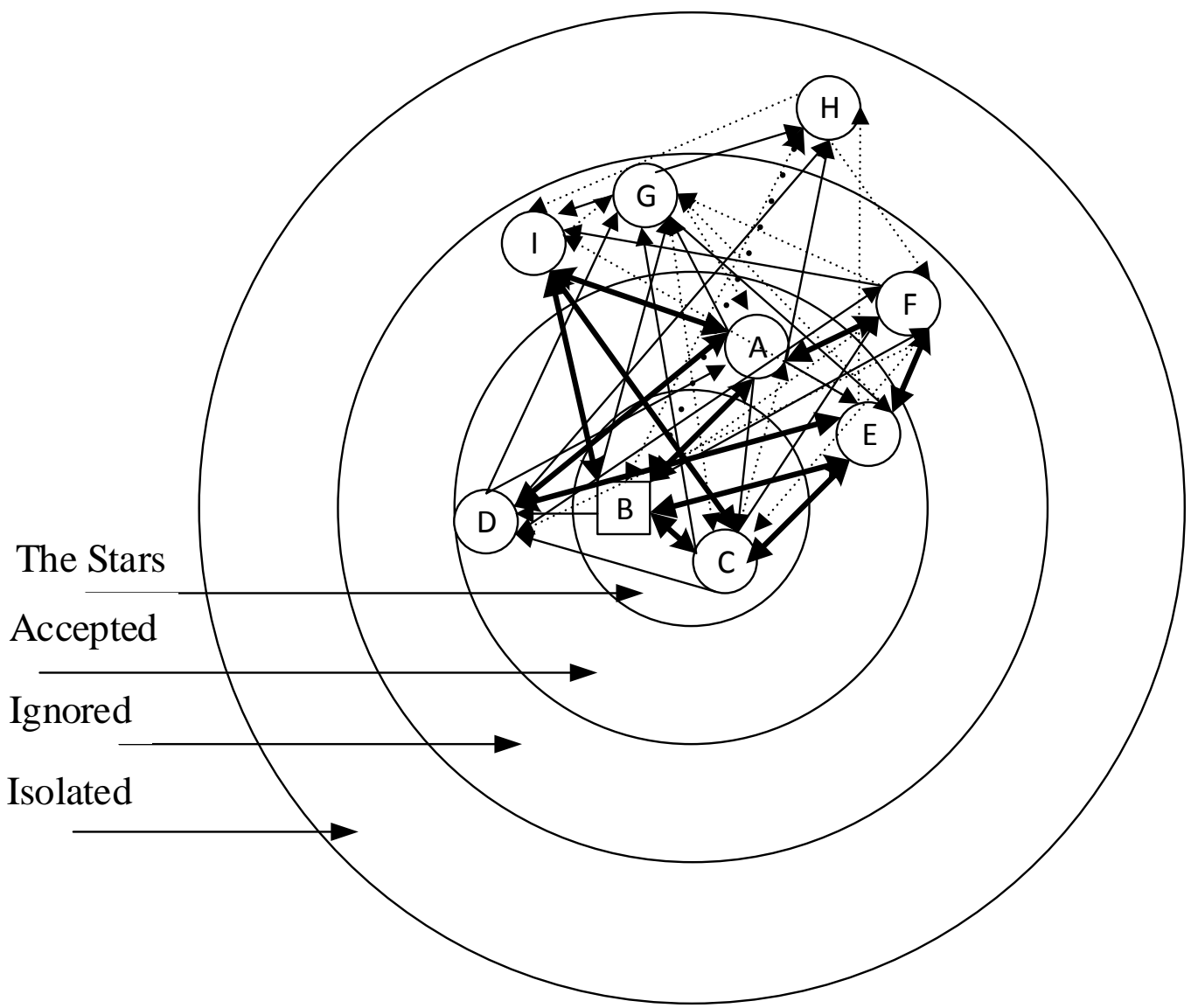

Fig. 3. Target Sociogram, built for tested pharmacy institution "A"

On the basis of these results, popularity ratings are conducted and positions of experts in the structure of interpersonal relations are determined. The rating for pharmacy specialists "A" is shown in Fig. 4, the distribution of pharmacy specialists by groups - Fig. 5 and Table 3. 
Table2

Summary sociometric table for tested pharmacy "A"

\begin{tabular}{|c|c|c|c|c|c|c|c|c|c|}
\hline No. & $\begin{array}{c}\text { Number } \\
\text { of posi- } \\
\text { tive } \\
\text { elections }\end{array}$ & $\begin{array}{c}\text { Number } \\
\text { of nega- } \\
\text { tive elec- } \\
\text { tions }\end{array}$ & $\begin{array}{c}\text { Number } \\
\text { of posi- } \\
\text { tive elec- } \\
\text { tions of } \\
\text { the i-th } \\
\text { specialist }\end{array}$ & $\begin{array}{c}\text { The num- } \\
\text { ber of } \\
\text { negative } \\
\text { choices of } \\
\text { i-th spe- } \\
\text { cialist }\end{array}$ & $\begin{array}{c}\text { Socio- } \\
\text { metric } \\
\text { status } \\
\text { index }\end{array}$ & $\begin{array}{c}\text { Emotion- } \\
\text { al expan- } \\
\text { siveness } \\
\text { satisfac- } \\
\text { tion with } \\
\text { the situa- } \\
\text { tion in the } \\
\text { team }\end{array}$ & $\begin{array}{c}\text { The coef- } \\
\text { ficient of } \\
\text { interper- } \\
\text { sonal } \\
\text { compati- } \\
\text { bility }\end{array}$ & $\begin{array}{c}\text { Conflict } \\
\text { Index }\end{array}$ \\
\hline 1 & 7 & 0 & 5 & 2 & 0.88 & 0.38 & 1 & 0.5 & 0 \\
\hline 2 & 7 & 1 & 4 & 2 & 0.75 & 0.25 & 0.88 & 0.5 & 0.13 \\
\hline 3 & 6 & 1 & 5 & 2 & 0.63 & 0.38 & 0.86 & 0.38 & 0 \\
\hline 4 & 5 & 0 & 5 & 1 & 0.63 & 0.50 & 1 & 0.25 & 0 \\
\hline 5 & 5 & 3 & 7 & 0 & 0.25 & 0.88 & 0.63 & 0.63 & 0 \\
\hline 6 & 3 & 4 & 4 & 1 & -0.13 & 0.38 & 0.43 & 0.13 & 0 \\
\hline 7 & 3 & 2 & 4 & 3 & 0.13 & 0.13 & 0.6 & 0 & 0 \\
\hline 8 & 1 & 3 & 4 & 2 & -0.25 & 0.25 & 0.25 & 0 & 0.25 \\
\hline 9 & 6 & 1 & 5 & 2 & 0.63 & 0.38 & 0.86 & 0.38 & 0 \\
\hline
\end{tabular}

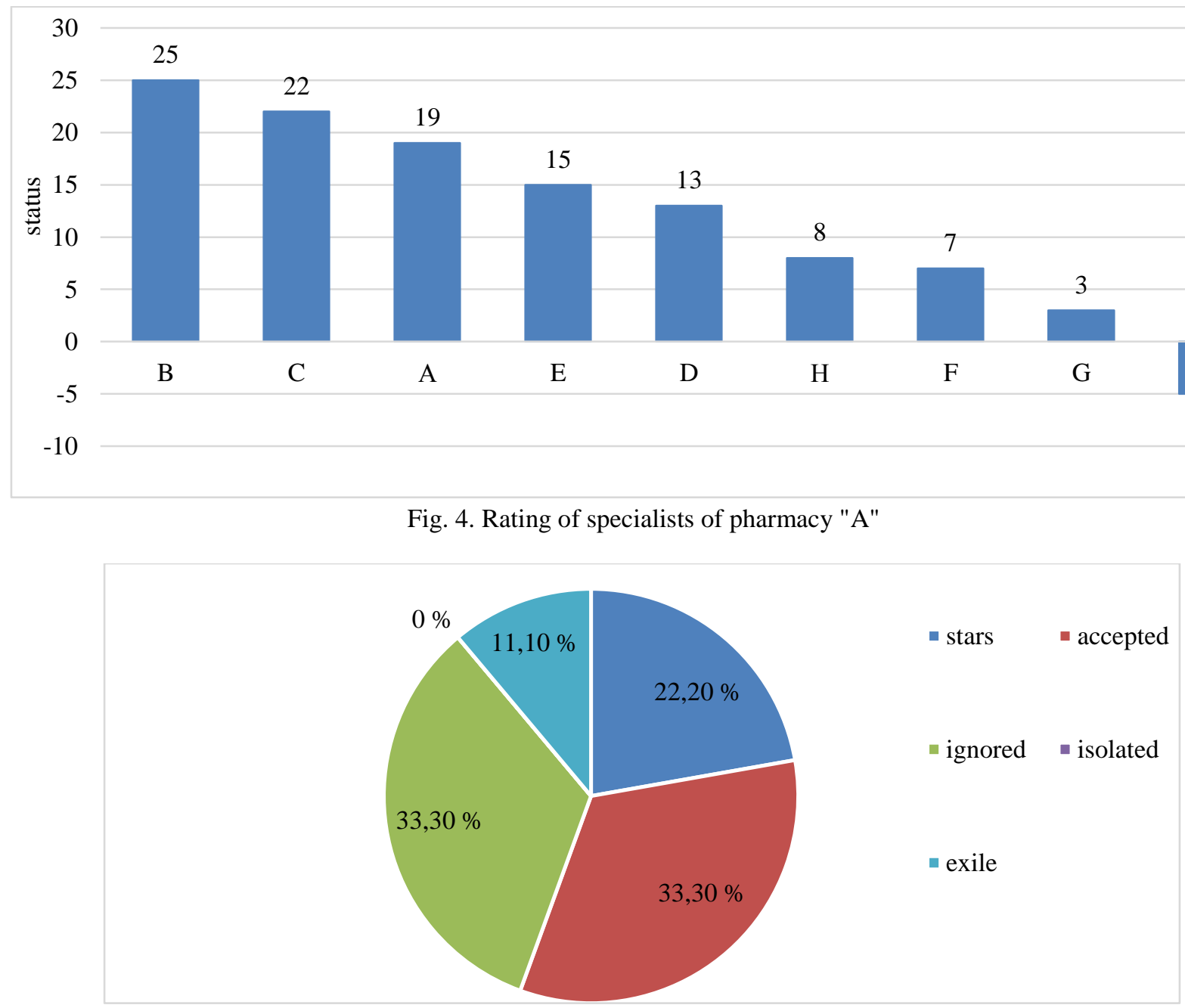

Fig. 5. The distribution of groups of pharmacy specialists for the tested pharmacy "A"

Table 3

Rating of pharmacy specialists who work in pharmacy "A"

\begin{tabular}{|l|l|c|c|}
\hline Categories & \multicolumn{3}{|c|}{ Pharmacy specialist's name } \\
\hline The Stars & $\mathrm{B}$ & $\mathrm{C}$ & $\mathrm{D}$ \\
\hline Accepted & $\mathrm{A}$ & $\mathrm{G}$ & $\mathrm{E}$ \\
\hline Ignored & $\mathrm{F}$ & $\mathrm{I}$ \\
\hline Isolated & $\mathrm{H}$ & & \\
\hline
\end{tabular}




\section{Discussion}

Thus, the analysis of the results allows us to conclude that in the PHI team a significant part of the pharmacy specialists are ignored and isolated, which requires the management of the institution to make certain decisions on personnel management, staff rotation and certain measures to improve the socio-psychological climate that has developed in the team in pharmacies.

The proposed approach differs from the approaches of other scientists in the complexity of determining the level of social and psychological climate in the team, because some scientists only study the index of sociometric status; others are just a socio-matrix. Studies of both domestic and foreign scientists do not concern pharmacy.

A restriction of the research is the number of pharmacy professionals who work in the pharmaceutical institute, their minimum cannot be less than 3 .

Sociometric studies have revealed formal and informal relationships within the team, so the pharmacy manager is $\mathrm{C}$, and one of the leaders is $\mathrm{B}$. Two pharmacy professionals, $\mathrm{C}$ and $\mathrm{G}$, have high levels of conflict that significantly affect relationships in the pharmacy.

\section{Conclusions}

The expediency of using the sociometric method for estimating the socio-psychological climate prevailing in the pharmacy institution is substantiated.
An algorithm is proposed for conducting a sociometric study in a pharmacy institution, which is proposed to be carried out in seven stages: collecting preliminary information about the staff of the pharmacy institution and preparing its list; development of a sociometric map; conducting a sociometric survey of team members; processing the results of a sociometric survey; analysis of the obtained sociometric data; interpretation of the obtained sociometric data; development of measures to improve the socio-psychological climate in the pharmacy.

A sociometric card was developed to evaluate the socio-psychological climate of the pharmacy, which contains six questions, three of which are positive and three are negative.

The form of the summary socio-matrix, which is a table with the distribution of individual choices, characterizing the relationship between a pharmacy specialist and members of the labor collective, consumers, partners or other persons is proposed.

It is suggested to determine the magnitude of sociometric status, the coefficient of conflict, emotional expansiveness, satisfaction with the position in the collective and interpersonal compatibility of pharmacy specialists.

\section{Conflict of interest}

No conflict of interest

\section{References}

1. Popov, D. G. (2009). Moral-psychological status of officials and social-psychological climate of work collective. Legal psychology, 4, 26-29.

2. Aikins, J. W., Litwack, S. D. (2011). Prosocial skills, social competence, and Popularity. New York: The Guilford Press, 356.

3. Aronson, E., Wilson, T. D., Akert, R. (2014). Sozialpsychologie. Hallbergmoos: Pearson, 201.

4. Bossaert, G., Colpin, H., Pijl, S. J., Petry, K. (2013). Truly included? A literature study focusing on the social dimension of inclusion in education. International Journal of Inclusive Education, 17 (1), 60-79. doi: http://doi.org/10.1080/ 13603116.2011. 580464

5. Berkowitz, L. (2008). On the consideration of automatic as well as controlled psychological processes in aggression. Aggressive Behavior, 34 (2), 117-129. doi: http://doi.org/10.1002/ab.20244

6. Scott, J. (2013). Social Network Analysis. Los Angeles, 51.

7. Cillessen, A. H. N. (2011). Toward a Theory of Popularity. New York: The Guildford Press, 426.

8. Cillessen, A. H. N., Marks, P. E. L. (2011). Conceptualizing and Measuring Popularity. New York, London: The Guildford Press, 183.

9. Schwartz, D., Gorman, A. H., Nakamoto, J., McKay, T. (2006). Popularity, social acceptance, and aggression in adolescent peer groups: Links with academic performance and school attendance. Developmental Psychology, 42 (6), 1116-1127. doi: http://doi.org/10.1037/0012-1649.42.6.1116

10. Dollase, R. (2013). Soziometrie - Anfänge, historische Entwicklung und Aktualität. Soziometrie. München: Springer VS, 15-29. doi: http://doi.org/10.1007/978-3-531-18981-9_1

11. Tolochko, V. M., Mishchenko, I. V., Artiukh, T. O. (2015). Orhanizatsiino-psykholohichni aspekty upravlinnia robochoiu hrupoiu. Kharkiv: NFaU, 28.

12. Maklakov, A. G. (2009). Obschaia psikhologiia. Saint Petersburg: Piter, 482.

13. Vasilchenko, O. P. (2011). Socialno-psikhologicheskii klimat - diagnostika i formirovanie. Spravochnik kadrovika, 8, 8-9.

14. Popova, G. V., Bogdan, Zh. B. (2014). Sociometricheskoe issledovanie dinamicheskikh processov v maloi gruppe. Warszawa: Diamond trading tour, 36.

15. Kalashnikova, A. E. (2014). Socio-psychological climate in the workplace. Psychology, Sociology and Pedagogy, 5 (32). Available at: http://psychology.snauka.ru/2014/05/3177 
Natalia Andrienko, Postgraduate Student, Department Processes and Apparatuses of Chemical and Pharmaceutical Industries, National University of Pharmacy, Pushkinska str., 53, Kharkiv, Ukraine, 61002

E-mail: paft@nuph.edu.ua

Rita Sahaidak-Nikitiuk, Doctor of Pharmaceutical Sciences, Head of Department,Department of Processes and Apparatuses of Chemical and Pharmaceutical Industries, National University of Pharmacy, Pushkinska str., 53, Kharkiv, Ukraine, 61002

E-mail: sagaidak_rita@ukr.net

Natalia Demchenko, PhD, Associate Professor, Department of Management and Administration, National University of Pharmacy, Pushkinska str., 53, Kharkiv, Ukraine, 61002

E-mail: demchenata@ukr.net

Natalia Alekhina, PhD, Associate Professor, Department of Pedagogy and Psychology, National University of Pharmacy, Pushkinska str., 53, Kharkiv, Ukraine, 61002

E-mail: alexinanata76@gmail.com

УДК 615.32+582.929.

DOI: 10.15587/2519-4852.2019.178320

\section{FATTY ACID COMPOSITION OF COMMON BUGLE HERB (AJUGA REPTANS L.)}

\section{A. Grytsyk, S. Maliuvanchuk}

Мета. Ідентифікаџія та визначення якісного складу та кількісного вмісту жирних кислот у траві горлянки повзучої.

Методи дослідження. Дослідження жирних кислот горлянки повзучої проводили методом газової хромато-мас- спектрометрії, який заснований на утворенні метилових естерів жирних кислот з наступним їх визначенням.

Результати дослідження. Методом хромато-мас-спектрометрії вперше проведено вивчення жирнокислотного складу трави горлянки повзучої (Ajugareptans L.). В результаті дослідження в траві горлянки повзучої було виявлено 22 речовини, з них ідентифіковано - 9 жирних кислот. За кількісним вмістом переважали поліненасичені - ліноленова та лінолева жирні кислоти та насичені - пальмітинова. Їх загальний вміст в перерахунку на суму жирних кислот складав 56,71\% (ненасичені), 28,18\%- насичена. В незначній кількості виявлені - стеаринова, ейкозанова, тетракозанова, бегенова кислоти (6,65\%).

Висновки. Жирні кислоти є важливими біосполуками, які беруть участь у складних метаболічних шляхах, є істотними компонентами ліпідів і клітинних мембран у вигляді фосфоліпідів, тим самим мають велику біологічну роль.

В траві горлянки повзучої в значній кількості містилися ненасичені жирні кислоти, вміст суми яких дорівнював 4706,78 мг/ка, щз майже в 1,4 рази вище вмісту суми насичених жирних кислот (3380,83 мг/к2). Результати досліджень можуть бути використані при розробиі методів контролю якості на сировину горлянки повзучої та одержанні біологічноактивних субстанцій з досліджуваної сировини

Ключові слова: горлянка повзуча, газова хромато-мас-спетрометрія,, жирні кислоти, насичені кислоти,ненасичені кислоти

Copyright (C) 2019, A. Grytsyk, S. Maliuvanchuk. This is an open access article under the CC BY license (http://creativecommons.org/licenses/by/4.0).

\section{Introduction}

Ajuga reptans - perennial plant from the Lamiaceae family. The natural area of the bugle growth is quite widespread: throughout Europe, in the Mediterranean, Asia Minor, Central Asia, China, the Balkan Peninsula, as well as in Afghanistan and Iran, it is also found in North America. It grows in meadows and shrubs, in forest glade and forest edges $[1,2]$.
Many plants of Ajuga genus are used in traditional medicine as a remedy for fever, toothache, dysentery, malaria, high blood pressure, diabetes, gastrointestinal disorders as anthelminthic, diuretic and antifungal, antiinflammatory and anti-mycobacterial agents [3].Some of them also used as insect growth inhibitors. A large number of compounds have been isolated from plants of this genus, including phytoecdysteroids, diterpenoids, triter- 